\title{
Neo-Ottomanism and Cool Japan in comparative perspective
}

\author{
Murat Ergin 1 and Chika Shinohara
}

\begin{abstract}
Turkey and Japan have comparable histories of modernization beginning in the nineteenth century. They have since then produced modernities that are considered a mix of "Eastern" and "Western." Over recent decades, both faced the question of what comes after modernity and began manufacturing their versions of authenticities and cultural exports. This paper comparatively locates two symptoms of this process. "Neo-Ottomanism" refers to the increasing cultural consumption of Turkey's imperial past while "Cool Japan" emphasizes popular products in entertainment, fashion, youth culture, and food, intending to shift Japan's image to a "cool" place. Both projects, in different ways, are sponsored by the state; yet their reception in popular culture illustrates the vexed relationship between the state and culture: while states endeavor to colonize culture for their own interests, popular culture provides avenues to outwit the state's attempts. Popular culture's autonomy in both contexts has to do with the collapse of traditional hierarchies, which has paved the ways for the promotion and export of new identity claims. Local and global representations of neo-Ottomanism and Cool Japan differ. Internally, they are fragmented; externally, they are linked to international "soft power," and offer alternatives modernities in Turkey and Japan's regional areas of influence.
\end{abstract}

Keywords: popular culture; state; soft power; Turkey; Japan

\section{Introduction}

Popular culture in Turkey and Japan has witnessed a great degree of commercialization and freedom from state control since the 1990s. The landscape of culture increasingly oriented toward pleasure, play, and consumption in a process in which symbols, ideas, objects, and histories are now commercially

Murat Ergin, Department of Sociology, Koç University, Turkey; muergin@ku.edu.tr.

Chika Shinohara, Department of Sociology, Momoyama Gakuin University (St. Andrew's University),

Japan; shinohc@andrew.ac.jp. 
appropriated, reinterpreted, decontextualized, and juxtaposed to one another in unprecedented cultural pastiches. ${ }^{1}$ Turkish and Japanese pasts have become the subjects of popular consumption in an increasingly commercialized cultural field, not only in these two countries but also globally. ${ }^{2}$ Turkish popular culture is a leading force in the Middle Eastern entertainment industry today while Japanese cultural exports have been a pioneer of the East Asian pop cultural booms such as the Korean Hallyu wave or Chinese Huallywood films from Hong Kong, Taiwan, and the continent. ${ }^{3}$ In both Turkish and Japanese contexts, the reevaluation of the past and marketing the country for domestic and international audiences represent renegotiations with modernity and the question of what comes after modernity. In this process, both Turkey and Japan have manufactured and exported their versions of cultural authenticity: neo-Ottomanism and Cool Japan, two attempts to rewrite the past in the contemporary context of alternative modernities and neoliberal transformations.

This paper pursues the comparison between Turkey and Japan by analyzing media discourse, political sources, and academic publications regarding how neo-Ottomanism and Cool Japan offer insights into state-culture relationships and the contingencies embedded in the domestic and international receptions of cultural products. Our main goal is to examine overlapping and sometimes dissimilar responses to global transformations that affected both Turkey and Japan. Westernization, characterized by the tense relationship between "tradition" and "modernity," is the first transformation that began in both settings in the nineteenth century. In many ways, neo-Ottomanism and Cool Japan represent trajectories in search of redefining modernity and reintegrating an imagined tradition into modernity. Neoliberal globalization is the second broad force that undermines the state's authority on culture and identifies neo-Ottomanism and Cool Japan as sites of encounter between governmental intervention and popular cultural consumption.

Against the backdrop of modernization and neoliberalism, we develop two main arguments. First, neo-Ottomanism and Cool Japan reveal that state-centric efforts to use culture as soft power create tensions with popular cultural representations that interpret the past in decontextualized and irreverent ways.

1 len Ang, Living Room Wars: Rethinking Media Audiences for a Postmodern World (London and New York: Routledge, 1996).

2 Murat Ergin and Yağmur Karakaya, "Between Neo-Ottomanism and Ottomania: Navigating State-Led and Popular Cultural Representations of the Past," New Perspectives on Turkey 56 (2017): 33-59;

Andrew D. Gordon, "Consumption, Consumerism, and Japanese Modernity," in The Oxford Handbook of the History of Consumption, ed. Frank Trentmann, 485-504 (Oxford: Oxford University Press, 2012).

3 Koichi Iwabuchi, Eva Tsai, and Chris Berry, Routledge Handbook of East Asian Popular Culture (London and New York: Routledge, 2017). 
At the center of this tension sits the uneasiness between former modernizationist ways of interventionism, which view culture as a domain of ideological transfer and search for "correct" history, and contemporary neoliberal emphasis on the past as a source of consumption for play and pleasure. While statesponsored visions of the past emphasize conquest and historical truth, popular cultural visions embellish conspicuous consumption, play, and sex appeal. Second, neo-Ottomanism and Cool Japan represent alternative and exportable modernities for both domestic and regional audiences. Contemporary neoliberal restructuring brings formerly rejected visions of "tradition" to the center stage of consumption as commodity. In the commercialized cultural field, the boundaries between "tradition" and "modernity" become porous as the West loses its discursive monopoly over modernization. While local audiences in Turkey and Japan consume the past in ways that envision alternative futures of being modern, exporting these modernities to international audiences becomes problematic because of the persistently negative receptions of imperial legacies in surrounding countries.

We intend to show how neo-Ottomanism and Cool Japan offer overlapping responses to the anxieties of modernization, neoliberal commercialization of culture, and exigencies of crafting and presenting an appealing national identity for domestic and global audiences in the contemporary world of branding nations. However, it is also important to recognize significant contextual dissimilarities. Neo-Ottomanism glorifies and exports Turkey's imperial past while Cool Japan is more oriented toward Japan's present and recent history. Turkey and Japan have different positions in their regional settings and different aspirations in marketing national cultures for regional and global audiences. An important comparison emerges from the similarity and dissimilarity of responses to global transformations, especially when we consider how these responses are percolated through contextual differences. In the following, we first start with the invention of Cool Japan and neo-Ottomanism under neoliberal globalization. After illustrating the tensions between culture as a state project and as a product of popular consumption, we turn to the pasts that these two contemporary projects rewrite and discuss the role of comparable histories of modernization in the formation of specific cultural imaginations. We then discuss the significance of modernity as an image to be both consumed locally and exported globally.

\section{The state and popular culture in neoliberal globalization}

\section{Nation branding: neo-Ottomanism and Cool Japan as state projects}

Despite their vibrant presence as autonomous consumption items in popular culture, both neo-Ottomanism and Cool Japan have the distinct footprints of 
political intervention in culture. The 1990s for Japan, popularly known as the Lost Decade (Ushinawareta Jünen), was a crises-ridden decade that ended in 2001 and proved to be a setback for the nation's self-confidence. For Turkey, an emphatic end to the crises-ridden 1990s came with a deep economic crisis in 2001. In both contexts, the early 2000s were marked by a search for changing the global image of the countries under conservative governments. Both governments turned to a vision of a glorified past to accomplish this goal. Cool Japan was an explicitly planned and methodically executed government invention for the purpose of countering Japan's unattractive workaholic image and rebranding it as a nation of "cool." For Turkey, the revival of the Ottoman past has served as a model for restructuring the government's diplomatic relations, cultural and educational policies, and urban transformation efforts. Although its advent was gradual and its political push less coordinated, neo-Ottomanism proved to be an appealing narrative for reimagining the country as a regional, if not global, power in search of its destiny for greatness. In both contexts, tensions arose between how the state officials imagined and recreated the country's image and how popular culture turned imagined national pasts and presents into popular consumption items.

The rising interest in Turkey's Ottoman past, called "Ottomania" by the international media, ${ }^{4}$ represents a process of reevaluating Turkey's historical heritage in the neoliberal era. ${ }^{5} \mathrm{Neo}$-Ottomanism signals the changing priorities in Turkey's domestic politics and international relations. Illustrated by the foundational text Strategic Depth, a book penned by Ahmet Davutoğlu, the minister of foreign affairs from 2009 to 2014, the foreign policy facet of neo-Ottomanism envisions a contemporary pax Ottomanica in the former territories and influence areas of the Ottoman Empire (1299-1923). This vision imagines a revival of the economic and social stability associated with Ottoman rule in the region. The foreign policy leg of neo-Ottomanism has resulted in Turkey's increasing ties with Middle Eastern and Balkan countries at the expense of Turkey's traditional diplomatic focus on the West. ${ }^{6}$ In domestic politics, the ruling Justice and Development Party identifies the Ottoman past as one of the central paradigms of their vision. Historical events in the imperial past, such as the capture of Istanbul, draw increasingly zealous celebrations. Other government-controlled venues, such as school textbooks and currency banknotes, revitalized

4 Dan Bilefsky, "Frustrated with West, Turks Revel in Empire Lost," New York Times, December 5, 2009. Ergin and Karakaya employ "Ottomania" and "neo-Ottomanism" to distinguish between popular cultural and state-centric aspects. See: Ergin and Karakaya, "Between Neo-Ottomanism and Ottomania."

5 Chien Yang Erdem, "Ottomentality: Neoliberal Governance of Culture and Neo-Ottoman Management of Diversity," Turkish Studies 18, no. 4 (2017): 710-28.

6 Ergin and Karakaya, "Between Neo-Ottomanism and Ottomania"; Nora Fisher Onar, "Constructing Turkey Inc.: The Discursive Anatomy of a Domestic and Foreign Policy Agenda," Journal of Contemporary European Studies 19, no. 4 (2011): 463-73. 
Ottoman-related themes. Finally, intensifying attempts shape the contemporary urban fabric with a nostalgic view to the Ottoman past. ${ }^{7}$

Similar to "Ottomania," the state tries to control "Japanmania" or Cool Japan, which represents a cultural phenomenon of recognizing and revaluing Japan's contemporary creativity and past cultural heritage. Before the state turned its attention in this direction, consumable culture as a source of pride attracted little attention in Japan. Products associated with Cool Japan were at best seen as simple entertainment for kids and at worst as the infantile fantasies of the geeky and obsessive otaku culture. ${ }^{8}$ What changed all of this was the increasing global consumption of Japanese culture beginning around the 1990s, which was seen a new type of international political power. In 2002, an American journalist, Douglas McGray, published an essay on Japanese popular culture as Japan's newly invented soft power in Foreign Policy, a US political news magazine. ${ }^{9}$ A socio-political news magazine in Japan, Chūo Kōron (since 1887, Chūokōron-Shinsha, Inc.), published the article with a Japanese translation in 2003. The translation was printed in the magazine's feature section, "Theorizing the Japanese State of Culture" (Nibon Bunkarikkokuron), with its new Japanese title, "Emerging Power as National Cool: World Striding Cool Japan" (Nashonaru Kürutoiu Aratana Kokuryoku: Sekaiwo Kapposuru Nipponno Kakkoyosa). The phrase "Cool Japan" was used for the first time. Thus, the concept was created by the Japanese cultural industry and soon promoted via the industry and political media. This helped distribute the idea that Japan's local popular culture became a powerful tool for its economic recovery and international relations.

However, it is important to note that McGray's article was not the initial impetus for the manifestation of Japan as a cool cultural creator, but it was actually a Japanese political lead. We discovered that, a few months before the article appeared, the governing Liberal Democratic Party had already implemented the "Basic Act for Promotion of Culture and the Art" in November 2001 and subsequently the Cabinet Office of Japan had launched its Intellectual Property Strategic Council in March 2002. ${ }^{10}$ The publication of McGray's article in the May/June issue of the magazine came a few months after the council's meeting. Unlike the term neo-Ottomanism (yeni Osmanliclik), which, taken up mainly among academic circles, was cold-shouldered by government officials, the Japanese phrase küru Japan or Cool Japan started appearing from 2003 in the records of national political discussions and major daily newspapers such as Nikkei, Yomiuri,

7 Ozan Karaman, "Urban Neoliberalism with Islamic Characteristics," Urban Studies 50, no. 16 (2013): 3412-27.

8 Hiroki Azuma, Otaku: Japan's Database Animals (Minneapolis: University of Minnesota Press, 2009); Hiroki Azuma, Nihonteki Sōzōryokuno Mirai: Kūru Japanorojīno Kanōsei (Tokyo: NHK Books, 2011).

9 Douglas McGray, "Japan's Gross National Cool," Foreign Policy, no. 130 (2002): 44-54.

10 Cabinet Office of Japan, "Kaisaijōkyō," Chitekizaisansenryakukaigi (March 20, 2002 to January 16, 2003). Retrieved on March 19, 2015 from www.kantei.go.jp/jp/singi/titeki/kaisai-dex.html. 
Asabi, and Mainichi. In 2003, a new national policy was formed with the intention to support intellectual property in Japanese pop culture. In order to create a "Japan brand," the policy was codified into annual Intellectual Property Strategic Programs. ${ }^{11}$ Additionally, Cool Britannia of the 1990s UK popular media culture was another likely inspiration for Cool Japan. Quite a few government ministries since then have adopted similar policy initiatives supporting the concept and promulgation of Cool Japan. ${ }^{12}$ Such policies promote Japanese cultural contents or "contents industries" such as media-induced "contents tourism," indicating that this is a government-led "nation branding" strategy+ ${ }^{13}$

\section{Neo-Ottomanism and Cool Japan in popular culture}

Despite state efforts to control the images of neo-Ottomanism and Cool Japan, their spread can be traced to the increasingly commercialized popular culture that was eager to display and market the past as a consumption item. Contemporary Turkey displays nostalgia for its Ottoman past across a multitude of media. Millions tune in to TV series with themes of Ottoman history, including warfare, palace intrigues, and romantic relations. Period dramas play an important role in shaping patterns of cultural consumption. For example, following Mubteşem Yüzyll (Magnificent Century, broadcast 2011-14), the TV persona of Hürrem (1502-88) - the wife of Sultan Süleyman the Magnificent (r. 1520-66) - shaped female fashion. This was a primetime soap opera that generated high ratings in Turkey, the Middle East, and the Balkans, but also led to controversy in Turkey because of the way it showed the intimate lives of sultans. As of 2018, the program has been broadcast in over seventy countries and regions and also aired in Japan during the summer of $2017 .{ }^{14} \mathrm{Netflix}$ website claims that it has been broadcast over fifty countries. ${ }^{15}$ However, these sources state the numbers without

11 Michal Daliot-Bul, "Japan Brand Strategy: The Taming of 'Cool Japan' and the Challenges of Cultural Planning in a Postmodern Age," Social Science Japan Journal 12, no. 2 (2009): 247-66.

12 The Cabinet Office of Japan lists Cool Japan-related ministries and offices in the government: Ministry of Internal Affairs and Communications; Ministry of Foreign Affairs; National Tax Agency; Agency for Cultural Affairs; Ministry of Agriculture, Forestry, and Fisheries; Ministry of Economy, Trade, Industry; Tourism Agency; and Ministry of Environment. See, Cabinet Office of Japan, "Kūru Japan senryaku," 2020. Retrieved on February 1, 2020 from www.cao.go.jp/cool_japan/about/ about.html.

13 Phillip Seaton and Takayoshi Yamamura, "Japanese Popular Culture and Contents Tourism," Japan Forum 27, no. 1 (2015): 1-11; Takeshi Matsui, "Nation Branding through Stigmatized Popular Culture: The 'Cool Japan' Craze among Central Ministries in Japan," Hitotsubashi Journal of Commerce and Management 48, no. 1 (2014): 81-97; Katja Valaskivi, "A Brand New Future? Cool Japan and the Social Imaginary of the Branded Nation," Japan Forum 25, no. 4 (2013): 485-504.

14 Hurriyet Daily News, "Turkey Ranks Second in TV Series Exports: Minister," November 17, 2017. Retrieved on July 25, 2018 from www.hurriyetdailynews.com/turkey-ranks-second-in-tv-seriesexports-minister-122562.

15 Netflix. 2018. Magnificent Century. Retrieved on July 25, 2018 from www.netflix.com/title/80089559. 
providing specific country names. Other news articles mention "more than 100 countries, including Algeria, Morocco and Bulgaria" without providing more specific information. ${ }^{16}$ The popular interest in the Ottoman past was not limited to TV series. Restaurants across the country invented menus with dishes purported to be "Ottoman." Photography studios popped up to meet people's growing desire to have their pictures taken in Ottoman period costumes. The publishing industry offered books and magazines with popularized stories of the Ottomans. Ottoman language courses and antiquity collecting became increasingly trendy. Ottoman tughras, the calligraphic signature of sultans, started to decorate clothing and cars in urban streets. The hamam, or the traditional Turkish bath, was discovered by five-star hotels and health clubs as representative of the authentic Ottoman experience. The rising interest in the Ottoman past also found an enthusiastic ear outside of Turkey, as, in addition to Turkish films and TV drama series, pop music and games received growing attention, especially in the Middle East and the Balkans.

Similarly, traditional and contemporary Japanese culture has grown its popularity in Japan and other parts of the world. In fact, Japan today is full of reminders for self-exoticizing cultural manifestations. "Made-in-Japan" cultural products in entertainment, fashion, youth culture, and computer games became the achievement of the creative industry, transforming Japan's image from a dwindling economic giant with aging worker bees to a cool producer of in-demand pop culture. Japanese mass culture established its own status particularly in Asia and North America in the mid-1980s, earlier than its Turkish counterpart. An example of this early interest is the morning TV drama series Oshin (broadcast between 1983 and 1984). ${ }^{17}$ The drama is a life story of a poor girl named Oshin, born and raised during Japan's imperial period. Oshin became "a symbol of Japan's postwar emergence from hard times" in Japan and elsewhere. ${ }^{18}$ First internationally broadcast in Singapore in the following year, ${ }^{19}$ the drama series and film have been

16 Fatima Bhutto, "How Turkish TV Is Taking over the World," The Guardian, September 13, 2019. Retrieved on March 24, 2020 from www.theguardian.com/tv-and-radio/2019/sep/13/turkish-tvmagnificent-century-dizi-taking-over-world.

17 The TV drama series Oshin has been broadcast in most of the countries and regions in East Asia except for South Korea, where Japanese popular culture, including the TV programs and films, was officially censored after the Second World War until 1998 under the Anti-Ethnic Act Punishment Law (Korea Ministry of Government Legislation 2018). The film Oshin was released for the public in the country in 2013. The Japanese popular media and their related products have been gradually shown for official sale there since 1999.

18 Clyde Haberman, "In Japan, 'Oshin' Means It's Time for a Good Cry," New York Times, March 11, 1984. Retrieved on March 8, 2016 from www.nytimes.com/1984/03/11/arts/in-japan-oshin-means-it-stime-for-a-good-cry.html.

19 Yee-Kuang Heng, "Beyond 'Kawaii' Pop Culture: Japan's Normative Soft Power as Global TroubleShooter," The Pacific Review 27, no. 2 (2014): 169-92. Also see, NHK. 2008. "Archives Blog: Renzoku Terebishōsetsu Oshin Hankyōhen (2)," NHK (Nippon Hoso Kyokai or Japan Broadcasting Corporation). Retrieved on March 6, 2018 from www.nhk.or.jp/archives-blog/genre/drama/9785.html. 
distributed to around seventy countries and regions as of $2018 .^{20}$ Younger generations, in Japan and in other parts of the world, grew up watching Japanese films and TV programs. Locally popular Japanese manga-originated TV drama series as well as game entertainment shows and cooking competition series have been reproduced abroad. ${ }^{21}$ Likewise, popular movies have been replicated abroad, like The Ring (1998), Shall We Dance? (1996), and Gojira (the Godzilla series since 1953). Others have enjoyed watching anime shows, playing anime-based games, and shopping for related character toys. Pokémon (an abbreviated term for Poketto Monsutā or Pocket Monsters), for instance, initially appeared on the Nintendo Game Boy system and then as card trading games in 1996, followed by its TV anime series, movies, and manga, and most recently as Pokémon GO, a mobile application game in 2016. Cosplay, costume play or kosupure, dressing up as and representing Japanese anime or game characters, is a popular entertainment among the youth today. Local bookstores and online shops display a number of books promoting "Cool Japan" cultural stories, business strategies, anime, and many other aspects of modern youth culture that draw upon history and tradition and offer alternative forms of power through "immaterial labor". ${ }^{22}$ Contemporary Japanese culture also spread to other associated consumption items and merchandise, such as J-pop music and cute or kawaii character toys, such as Hello Kitty. ${ }^{23}$

\section{Tensions between the state and popular culture}

In the 1990s, both countries experienced economic crises and began soul searching regarding state-society relations. The state in Turkey and Japan has historically relied on an interventionist approach toward culture in order to buttress modernization. Turkish and Japanese governments were actively engaged in the creation and maintenance of neo-Ottomanism and Cool

20 Japan Foundation, "Terebibangumino Kaigaitenkai," 2018. Retrieved on July 25, 2018 from www.jpf. go.jp/j/project/culture/media/tv/index.html.

21 For example, Hanayori Dango (Boys over Flowers) —manga series 1992-2004, films (Fuji \& Toei 1995; Toho 2009), and TV drama series (TBS, 2005 and 2007)—have been reproduced as Liuxing Huayuan or Meteor Garden in Taiwan (TTV, 2001), as Kkot Boda Namja in South Korea (KBS, 2009) and China (Hannan Television, 2009, 2018), and in the United States as Boys before Friends (Willkinn Media, 2013). Ryorino Tetsujin or Iron Chef is a cooking competition show aired abroad and adopted in countries such as the United States (United Paramount Network; Food Network), United Kingdom (Channel 4), Israel (Channel 10), Australia (Seven Network), Thailand (CH7), and Vietnam (Vietnam Television).

22 See, e.g., Anne Allison, "The Cool Brand, Affective Activism and Japanese Youth," Theory, Culture \& Society 26, nos. 2-3 (2009): 89-111.

23 Shinji Miyadai, "Kawaii No Honshitsu," in Nihonteki Sōzōryokuno Mirai: Kūru Japanorojīno Kanōsei, ed. Hiroki Azuma, 73-91 (Tokyo: NHK Books, 2011); Laura Miller, "Cute Masquerade and the Pimping of Japan," International Journal of Japanese Sociology 20, no. 1 (2011): 18-29. 
Japan, reflecting this legacy of state intervention in culture, ${ }^{24}$ which was challenged by the recent neoliberal commercialization of popular culture. Neoliberal commercialization confronts previous anxieties about Westernization and instead generates attempts to indigenize modernity and rehabilitate a "tradition" putatively neglected during the search for modernity. Neo-Ottomanism and Cool Japan illustrates the vexed relationship between the state and popular culture in the neoliberal era. In both contexts, the state intended to create an invented past and a desirable present in line with its policy orientations. However, popular culture deviated from the state-imposed path and established its own indifferent, irreverent, and sometimes obsequious perspective toward history. While states endeavor to colonize the past through cultural means, popular culture on the contrary provides avenues to outwit these plans. The successful incorporation of neo-Ottomanism and Cool Japan into commercialized popular culture signals the challenges and limits to the power of the state as an actor in culture. For neo-Ottomanism, the rise of cultural commercialization, which was built on the consumption of the imperial past, was possible because of the increased relaxation and irrelevance of state-imposed top-down efforts to mold popular culture. Similarly, the weakened state control over popular culture subsequently paved the way for an extended Japanese popular culture.

Although popular culture has a voracious appetite for marketing the past, Ottoman and Japanese histories become targets of consumptions in different manners. Unlike the Ottoman Empire (1299-1923), the Empire of Japan (1866-1945) was a modern colonial-imperialist power and lasted for a short time exactly during Japan's rapid modernization and Euro-Americanization period. Neo-Ottomanism displays a more direct nostalgia for the imperial Ottoman period. While earlier cultural products, such as the period drama Magnificent Century, display examples of imperial feminine appeal, more recent shows intended for conservative audiences emphasize masculine and militarized narratives. Cool Japan also shows a nostalgia for the Japanese Empire; however, because of the more contentious military legacy of this period, the main interest revolves around imperial modernization. Therefore, cultural consumption targets elements from the imperial period when they are perceived as progressive and "cool." Although more recently some anime and game products, such as Kantai-collection (Kadokawa Shoten 2013), Strike Witches (Kadokawa Shoten 2006), and Girls und Panzer (Actas Inc. 2012) use the image of Japanese imperial militarism, it has been rare compared to the Turkish case. Japanese imperial pasts in popular

24 Murat Ergin, "On Humans, Fish, and Mermaids: The Republican Taxonomy of Tastes and Arabesk," New Perspectives on Turkey, no. 33 (2005): 63-92; Brian J. McVeigh, Nationalisms of Japan: Managing and Mystifying Identity, Asia/Pacific/Perspectives (Lanham, MD: Rowman \& Littlefield, 2004). 
consumption often include modernized, Westernized, and progressive cultural elements rather than militarism. In fact, in the context of East and Southeast Asia, for example, Cool Japan is utilized as public diplomacy to mitigate antiJapan sentiments resulting from its colonial military history. ${ }^{25}$

While the legacies of "empire" have different connotations in Turkey and Japan, this does not change the fact that "history" serves as a political tool and a consumption item. In both cases, policymakers design historical narratives to take advantage of people's yearning for their countries as historical superpowers, and the resulting cultural narratives capitalize on the allure of history in a commercialized cultural terrain. This double appeal of the past in political and popular cultural projects leads to inevitable tensions. While both governments promote particular forms of historical residues for service in contemporary political goals, these cultural projects are interpreted in irreverent ways in popular culture that may challenge state-centric visions of history. In this sense, societal receptions of the Turkish and Japanese nation-branding strategies transpire in a decentralized but integrated network of images, symbols, and items, ready for popular consumption and sometimes ripe for transgressing the policy goals of governments. Japan took advantage of the power of its popular culture from the beginning, given that the government introduced the Cool Japan Initiative as an attempt to present a globally palatable version of Japanese culture. In the Turkish case, the government pushed neoOttomanism mainly in foreign policy, education, and urban infrastructural projects. Consumption-oriented aspects of neo-Ottomanism build on stereotypical notions of feminine sensuality and leisure, especially in sectors that emphasize marketing the past, such as jewelry, cooking, fashion, and perfumes. The revealing clothing that palace women wore in the TV series Magnificent Century has created intense controversy among conservative segments of the population that blamed the show for spreading indecency. These depictions of Ottoman femininity resulted in a recent backlash and promoted conservative inroads into popular culture that emphasized masculinity, heroism, and religiosity. An example of the masculinist turn has to do with mushrooming period dramas, such as Resurrection Ertuğrul, which aggrandize Ottoman conquests and heroism while reducing women characters to auxiliary roles. Commemorative buildings, such as Istanbul's Museum of Conquest (Fetih Müzesi), and commemorative events, such as anniversary rallies of Istanbul's Conquest, have a similar masculine and military appeal. ${ }^{26}$

25 Koichi Iwabuchi, "Pop-Culture Diplomacy in Japan: Soft Power, Nation Branding and the Question of "International Cultural Exchange'," International Journal of Cultural Policy 21, no. 4 (2015): 419-32. 
Though the paths toward each of these contemporary reevaluations of past cultural traditions may have differed, the stimuli, goals, and end results of each remain largely similar. Neo-Ottomanism and Cool Japan represent efforts to rehabilitate the past in order to confront contemporary challenges. The past in both cases becomes an interpretive lens and a symbolic tool to negotiate with alternative forms of modernity in a neoliberal world. Accordingly, the collapse of traditional hierarchies between "high" and "popular" culture and the erosion of the trope of Western modernity have paved pathways for the promotion and export of new identity claims rooted in historical glory. Rehabilitating the past plays a prominent role in constructing alternative forms of modernity, because a complex constellation of historical residues shape efforts to engage with modernity in the forms of infrastructural projects to reclaim cities, campaigns to reshape education, creative outlets to refashion arts and cultural industries, and building identity claims to pursue historical continuities. The next section discusses the domestic and international appeal of alternative modernities originating from neo-Ottomanism and Cool Japan.

\section{Alternative and exportable modernities}

Turkey and Japan formed a complex relationship with modernity and identified the West both as a model to follow in pursuit of modernity and an intruder to avoid in protecting national identity. In both cases, modernizing elites considered Western modernity as a defensive weapon against the intrusions of the West. The result was shared anxieties toward Western influence and attempts to search for a proper mixing of "traditional" identities with modernity. While the dichotomies, such as "East" and "West," provided conceptual maps in the discursive landscape of modernization, scholars established the problematic nature of clear-cut boundaries as inaccurate representations of infinitely messier transformations. ${ }^{27}$ These burdens gave modernity an uncertain characteristic and led to searches for "alternative modernities" in the 1990s.

The Ottoman Empire and Japan experienced major reforms fewer than thirty years apart in the nineteenth century: the Tanzimat Renovation (1839) and the Meiji Restoration (1868). Beyond the temporal proximity, these imperial efforts to modernize have significant overlaps. First, both responded to increasing encounters with Western military superiority in the nineteenth and early twentieth centuries. As capitalism marched forward to open new markets across the globe, European and North American countries were trying to penetrate both empires economically and militarily. Thus, military pressure went hand in hand with economic expansionism. Second,

27 Naoki Sakai, "The West: A Dialogic Prescription or Proscription?" Social Identities 11, no. 3 (2005): 177-95. 
both reforms marked the beginning of a long period of modernization, in which vexed questions about national identity emerged. Ottoman (later Turkish) and Japanese modernizers pondered difficult questions about how to mix Western culture with traditional values. While Western superiority was accepted in a number of institutional domains as a fact, the contention was about what gave the West its defining features and what aspects of "traditional" identities had to be protected while modernizing. Third, for Western publics, the condition of women in the Ottoman and Japanese Empires epitomized their difference from the modern world. Because the modernizing elite were acutely aware of these perceptions, gender acquired symbolic significance in debates about how to incorporate Western modernity and maintain traditional values at the same time. In both contexts, modernization brought a number of legal measures to ensure equality, although substantive changes in the condition of women were much slower to come.

The rise of neo-Ottomanism and Cool Japan shows significant shifts concerning the creation of national identities with an eye in the past. Local fascination with the representations of contemporary neo-Ottomanism and Cool Japan combine elements of nostalgia and self-exoticization of the past. These attempts to sell "tradition" in the contemporary neoliberal world introduce new sensibilities to historical legacies and a more confident emphasis on popular cultural pleasures, which directly challenge didactic state-centrism toward culture. Internationally, popular culture operated as a collection of commodities to brand nations and market authenticity. Neo-Ottomanism and Cool Japan, in their veneration of the past, presented important challenges to the two-centuries-old discourses of modernization and raised the possibility that a different, and a decidedly non-Western, modernity could be envisioned, only to be exported to surrounding countries.

\section{Modernity and culture in Turkey}

Modernization has been a two-centuries-long affair in Turkey's Ottoman and republican past. Although Turkey was never colonized, modernization brought up identity issues resembling those in the colonial world. ${ }^{28}$ State interventions around the authenticity of culture took place as tools to make cultural value judgments in early modernizing Turkey. In order to examine the taxonomy envisioned to classify legitimate and illegitimate culture in a modernizing Turkey, we refer to three discourses around art, identified by Simon Frith. ${ }^{29}$ The art discourse strives for transcending time, space, and

28 Ayşe Kadıoğlu, "The Paradox of Turkish Nationalism and the Construction of Official Identity," in Turkey: Identity, Democracy, Politics, ed. Sylvia Kedourie, 177-93 (London and Portland, OR: Frank Cass, 1996).

29 Simon Frith, "The Good, the Bad, and the Indifferent: Defending Popular Culture from the Populists," Diacritics 21, no. 4 (1991): 102-15, at 106-7. 
the everyday. In this sense, the goal of art is to discover sublime emotions and ideas. The folk discourse integrates individuals into a space or community. The pop discourse provides "routinized pleasures" and "legitimized emotional gratification," hence emphasizing play and pleasure in art. The early republican modernizers in Turkey relied on art and folk discourses to make cultural judgments. Both discourses considered pleasures as harmful divergences from artistic or national pursuits. In this sense, culture was seen as a pedagogic tool in the hands of the state to transform society for a successful modernization. With the commercialization of the cultural field, the 1990s witnessed the dismantling of state-sponsored cultural judgments. ${ }^{30}$ The rise of private TV channels and radio stations challenged the state's monopoly on culture and discourses around pleasure began to overwhelm previously dominant art and folk discourses. Current internet technologies, social media, and music and video streaming platforms, all controlled by global corporations, intensify this process. Popular culture's embrace of neo-Ottomanism was the harbinger of this new constellation, signaling a new period in which culture began to uncouple from the state. Neo-Ottomanism is the first fully fledged trend in popular culture that does not have the insecurities of government-defined modernization and the official rejection of pleasure. Producers of neoOttoman popular culture, such as script writers, frequently defend themselves against critics by pointing out that their shows are only for entertainment. As culture became commercialized, the production and consumption of neo-Ottomanism followed the logic of cultural markets rather than the state's imposition. Instead of operating as cultural tools of modernization, neoOttomanism in popular culture was consumed as products of entertainment and pleasure. This was one of the reasons for the tensions between the state's vision of neo-Ottomanism and the irreverent ways in which it was consumed in cultural markets.

The declining role of the modernization paradigm in cultural evaluation has a significant consequence in the Turkish context: increasingly divergent evaluations of the imperial past as people consume it in popular culture. Four dominant discursive positions exist. ${ }^{31}$ Some see the Ottoman past as a burden for the country. Such a negative perspective was the default official position during Turkish modernization in the early twentieth century. Although increasingly becoming less popular, this view survives today. Some individuals in this camp believe that the Islamic imperial past is responsible for the country's current problems and, hence, they tend to feel a disguised shame about the atrocities committed during the Ottoman reign. However, the majority of

30 Ergin, "On Humans, Fish, and Mermaids."

31 Ergin and Karakaya, "Between Neo-Ottomanism and Ottomania." 
the population consumes the Ottoman heritage with a view to rehabilitate it in contemporary culture-this indicates efforts to challenge the singular state authority of the "modern" in popular culture and inserting the past into contemporary culture with a vision of alternative modernity. The position that is supported by the government today presents the imperial past as a golden age in which different religious and ethnic groups coexisted peacefully. For those to whom the Ottomans represent the epitome of tolerance, this model of coexistence can be used to deal with ethnic and religious conflict in contemporary Turkey. From another standpoint, some present the Ottomans as Turks, evaluating the imperial past in a language of ethnic descent. Finally, from the viewpoint of the fourth position, the Ottomans are the defenders of the Islamic faith. This perspective tends to construct an Islamic golden age in the Ottoman past and considers the contemporary period as an example of moral decay that can only be reversed by going back to past values and sensibilities. As neo-Ottomanism aligns these perspectives with consumption practices, the Islamic past we witness is the "harmonization" of Islam with neoliberal exigencies. ${ }^{32}$

\section{Self-exoticizing tendencies and cultural identity of Japan}

Cool Japan is an explicit governmental attempt to shape culture and to imagine a particular form of cultural identity. It does, however, have parallels to the Turkish case about its unapologetic emphasis on play and pleasure rather than envisioning culture as an educational tool. The emphasis on pleasure and playfulness is coupled with an uncharacteristically confident posture in presenting Japanese cultural products and corresponds to a period where Japanese youth culture is bolder than ever in opposing state-sponsored traditional authority. The work-oriented image of "Japan, Inc.," a country where the major driving force is the economy, began to change in the post-bubble economy of the 1990s. Until then, youth culture products, such as anime and manga, received serious criticism from the established media for being irresponsible and unable to "grow up." As the rising power of play or asobi, with its emphasis on pleasure and decadence, made its way into mainstream cultural domains in the 1990s, early responses saw the "universalization of youth playful culture" and "blurring the boundaries between childhood and adulthood." 33 The government's involvement in these cultural industries and the Cool Japan policy have also been criticized as a waste of tax money.

32 Nikos Moudouros, "The 'Harmonization' of Islam with the Neoliberal Transformation: The Case of Turkey," Globalizations 11, no. 6 (2014): 843-57.

33 Michal Daliot-Bul, "Asobi in Action: Contesting the Cultural Meanings and Cultural Boundaries of Play in Tokyo from the 1970s to the Present," Cultural Studies 23, no. 3 (2009): 355-80, at 366. 
Compared to Turkey, Japan's imperial past appears much less in its contemporary cultural exports. Cool Japan displays a self-exoticizing and self-congratulatory tendency through current accomplishments in popular culture. Although the imperial period is less frequently and less prominently reflected, when it is portrayed it is often illustrated with the poverty and struggles of the ordinary citizens, decontextualizing the forceful and violent, thus negative, image of Japanese past. Major popular cultural productions exported outside Japan are often animals or animal-like characters, such as Hello Kitty (Yuko Shimizu and Sanrio Co., Ltd.), Doraemon (Fujiko Pro and Shogakkan Inc.), and Pokémon. Curiously, Hello Kitty as a character was designed to have been born in London. Like this case, many Japanese products are designed to have a variety of "national origins," or to show "culturally odorless" characteristics to disguise its national identities. ${ }^{34}$ Other examples for Japanese cultural exports are human figures with either first- or second-hand connections to imaginary worlds, such as the Dragon Ball series (Bird Studio and Shueisha Inc.), Super Mario Bros game series (Nintendo Inc.), and Inuyasha (Rumiko Takahashi and Shogakkan Inc.).

Quite a few TV shows, such as Japan's public broadcasting channel NHK's aptly titled Cool Japan, demonstrate how Japanese culture can be objectified for popular consumption today. The popular and long-lasting entertainment show from 2006 to date is geared toward the domestic consumption of cool in Japan and was later discovered by foreigners. The sense of national pride embedded into this discovery is unmistakable and is quite similar to some of the local positions seen in the case of neo-Ottomanism. The same national pride can also be observed in government documents. For example, the 2005 Intellectual Property Policy asserts that one of the goals of the national policy is to "utilize [Japanese people's] outstanding capabilities in inventing and creating," later adding that this will help Japan "uphold an honored position in the world." 35 However, similar to the case of neoOttomanism, the local consumption of Japanese popular culture is equally contested. Going directly against the government attempts to regulate culture, "Cool Japan imageries are fragmented and pluralistic." 36 This is because the production and consumption sides of popular culture interact in ways that give us a complex domain in which consumer demands and corporate supply of culture shift in unexpected ways.

34 Koichi Iwabuchi, Recentring Globalization: Popular Culture and Japanese Transnationalism (Durham, NC and London: Duke University Press, 2002).

35 Daliot-Bul, "Japan Brand Strategy," 259-60.

36 Daliot-Bul, "Japan Brand Strategy," 249. 
From defensive to "offensive": exporting accessible modernities

The pleasure-oriented and playful cultures of neo-Ottomanism and Cool Japan represent an uncharacteristically confident posture in promoting Turkish and Japanese cultural products abroad. Defensive elements characterized imperial modernization, which spent a great deal of effort explaining and justifying cultural differences as insignificant bumps in the road in search for modernity. Today's cultural stance is akin to a more offensive posture. Turkish and Japanese popular cultures are actively seeking foreign audiences in the hope of capitalizing on cultural difference and marketing objects of desire. As Daliot-Bul observes in the context of Japan, the contemporary self-confidence points to a culture that it "is no longer designed to introduce Japan to the world or to explain Japanese behavior to non-Japanese but to create soft power by producing an influential national message." ${ }^{37}$ Both cultural projects have been attractive in their regional areas of influence because they offer accessible and imaginable modernities. The basis of this attraction, then, has to do with potentially creative ways of combining "tradition" and "modernity" in nonWestern ways that appeal to regional sensibilities. However, similar to their domestic consumption, global receptions of neo-Ottomanism and Cool Japan are complex and contested. While the shift from defensive modernization to offensive cultural exports indicate self-confidence, the international reception of neo-Ottomanism and Cool Japan can be "offensive" in another sense as Turkish and Japanese imperial pasts rest on centuries-old conflicts and hostilities, and ironically create challenges for the "soft power" they seek. ${ }^{38}$ The sustainability of their overall cultural impacts and their fates as diplomatic tools in the future remain open questions.

The global receptions of neo-Ottomanism and Cool Japan, as was the case with domestic consumption, show vexed and fragmented characteristics. While neo-Ottomanism represents a regenerated "tradition" challenging the country's dominant discourse of modernization, Ottoman-themed Turkish TV dramas garner immense popularity in Middle Eastern countries, not only because they portray Middle Eastern characters in heroic roles but also because they offer an "accessible modernity." 39 The depiction of beautiful and wellgroomed characters and modern, wealthy locations in these TV series convince the viewers that, despite differences in culture and language, the Turkish

37 Daliot-Bul, "Japan Brand Strategy," 258.

38 Alexander Bukh, "Revisiting Japan's Cultural Diplomacy: A Critique of the Agent-Level Approach to Japan's Soft Power," Asian Perspective, no. 38 (2014): 461-85; Yohanan Benhaïm and Kerem Öktem, "The Rise and Fall of Turkey's Soft Power Discourse," European Journal of Turkish Studies, no. 21 (2015), https://doi.org/10.4000/ejts.5275.

39 Marwan M. Kraidy and Omar Al-Ghazzi, "Neo-Ottoman Cool: Turkish Popular Culture in the Arab Public Sphere," Popular Communication 11, no. 1 (2013): 17-29. 
packaging of modernity does not feel like an alien concept but can be accessible to ordinary people in the Middle East. In the case of Japan, too, Japanese popular culture represents a form of indigenous modernity, ${ }^{40}$ which offers ways to maintain an essential Asian-ness while acquiring a form of Western modernity. ${ }^{41}$ In his study of Japanese popular culture in Taiwan, Koichi Iwabuchi questions the assumptions of "cultural proximity" as the only reason for the popularity of Japanese cultural exports in Asia. Emphasizing the significance of consuming an imagined modernity, he argues: "modernizing Asian nations are nostalgically seen to embody a social vigor and optimism for the future that Japan allegedly is losing or has lost." 42 As was the case for Turkish influence in the Middle East, cultural similarity cannot offer an explanation on its own. Both Turkey and Japan present alternative modernities in their areas of regional influence. Nevertheless, while the stories and characters in Turkish and Japanese popular media culture often symbolize modernity, they also package hierarchical and traditional patriarchal elements of the relationships of the family, corporate worker, and gender.

What makes exporting modernity challenging and the establishment of "soft power" complex has to do with Turkey's and Japan's imperial pasts. The idea of soft power implies that cultural exports through the popular media become powerful tools for constructing cultural understanding and sympathy abroad. ${ }^{43}$ However, exporting popular culture alone does not necessarily create cultural understanding. Thus, it is unclear whether the goal of promoting Japanese or Turkish culture is working in line with the expectations of "soft power." For example, the consumption of Cool Japan anime does not always indicate a serious interest in Japan and its culture, because most fans of a Cool Japan in the world today do not study Japanese history, language, or culture. They enjoy watching anime and J-drama series but are not necessarily interested in the country where the products of their consumption were produced. ${ }^{44}$ Moreover, Japan's soft power is hampered because of the perception of its imperial history. Shaping cultural markets does not equal exerting local political power, ${ }^{45}$ because “Japan's pursuit of 'soft power' and a good

40 Shuling Huang, "Nation-Branding and Transnational Consumption: Japan-Mania and the Korean Wave in Taiwan," Media, Culture \& Society 33, no. 1 (2011): 3-18; Koichi Iwabuchi, ed. Feeling Asian Modernities: Transnational Consumption of Japanese TV Dramas (Hong Kong: Hong Kong University Press, 2004).

41 Stefan Tanaka, Japan's Orient: Rendering Pasts into History (Berkeley: University of California Press, 1993).

42 Iwabuchi, Recentring Globalization, 159.

43 Joseph S. Nye, "Soft Power," Foreign Policy, no. 80 (1990): 153-71.

44 Jonathan E. Abel, "Can Cool Japan Save Post-Disaster Japan? On the Possibilities and Impossibilities of a Cool Japanology," International Journal of Japanese Sociology 20, no. 1 (2011): 59-72, at 63.

45 Nissim Kadosh Otmazgin, "Contesting Soft Power: Japanese Popular Culture in East and Southeast Asia," International Relations of the Asia-Pacific 8, no. 1 (2008): 73-101. 
international image" could be "undermined by its failure to overcome its burden of history" ${ }^{46}$ despite the demonstrated attractiveness of Japanese popular culture abroad. These observations also hold true for the Turkish case. Eager consumption of Turkish TV series does not imply that Middle Eastern publics unequivocally embrace Turkish culture, the Turkish language, or Turkey's diplomatic stance. ${ }^{47}$ There are deep-seated suspicions toward Turkey in the Middle East and those suspicions are consequently reciprocated by the people of Turkey, which may create a mismatch between the intended goal of neoOttomanist policies and their actual reception in the region. ${ }^{48}$ In both cases, it is unclear whether cultural influence turns into diplomatic and political power. Paradoxically, the very act of the serious study of Japanese culture potentially makes Cool Japan uncool and the serious study of Turkish culture potentially uncovers Ottoman-era traumas.

These challenges to Turkey's and Japan's "soft power" raise questions about the sustainability of neo-Ottomanism and Cool Japan as cultural and diplomatic projects. In Turkey, part of the population considers the recent developments in the Middle East as proof of the failure of Turkey's neo-Ottoman foreign policy. This is especially the case for those who consider neoOttomanism partially responsible for the millions of migrants that called Turkey home during the Syrian civil war. The constant shifts of alliances in the Middle East places the neo-Ottomanist diplomatic efforts on uncertain terrain. Moreover, the country's bid for EU membership appears to have halted after more than a decade, which, for many, makes the outlook of a modern/European future dim and Turkey's claim to becoming a regional power unrealistic. Similar uncertainties exist for Cool Japan. Japan's recent demographic shift to an overall, and particularly working, population decline, due to an aging population with low fertility, creates the socioeconomic conditions for an immigration influx within an immigration-restricted society. ${ }^{49}$ These demographic challenges and other concerns, such as transnational competition to the anime creative industry, could make many people in the country feel uneasy. ${ }^{50}$ Younger generations in creative industries today are often

46 Peng Er Lam, "Japan's Quest for 'Soft Power': Attraction and Limitation," East Asia 24, no. 4 (2007): 349-63, at 350.

47 Kraidy and Al-Ghazzi, "Neo-Ottoman Cool."

48 Fisher Onar, "Constructing Turkey Inc."

49 Chika Shinohara, "Health-Care Work in Globalization: News Reports on Care Worker Migration to Japan," International Journal of Japanese Sociology 25, no. 1 (2016): 7-26; Glenda S. Roberts, "An Immigration Policy by Any Other Name: Semantics of Immigration to Japan," Social Science Japan Journal 21, no. 1 (2018): 89-102.

50 Yoshitaka Mori, "The Pitfall Facing the Cool Japan Project: The Transnational Development of the Anime Industry under the Condition of Post-Fordism," International Journal of Japanese Sociology 20, no. 1 (2011): 30-42. 
working long hours for low pay and face competition against those workers with lower income levels in emerging Asian societies. Does the idea of Cool Japan have a place in such a world? In addition, the images of the tsunami, earthquakes, and nuclear disaster in Fukushima have been etched in the minds of people around the globe. In the wake of the 2011 triple disaster, Condry and Fujita alerted us to the fact that the image of Japanese society could possibly alter from cool to dangerous in terms of its global social and cultural sustainability. ${ }^{51}$

\section{Conclusion}

What explains the parallels between neo-Ottomanism and Cool Japan? In this comparative analysis, we offer a perspective to understand these experiences with branding the past. First, both countries have comparable historical backgrounds, especially in their dealings with modernization beginning 200 years ago. Both countries have comparable experiences of modernization, as early adopters of Western modernity in the nineteenth century. Concerns with Western intrusion led to anxieties about adopting an unproblematic modernity, which implied a "proper" mixing of "traditional" and "modern" elements. This also created the burden of explaining and justifying Turkish and Japanese cultures to Western audiences in moments of divergence from the project of modernization. The state in both countries attempted to watch and control culture closely as a tool of importing modernity. This history of control manifests itself in neo-Ottomanism and Cool Japan-both projects are linked to deliberate state policies of reviving an imagined past and exporting culture. Thus, the Turkish and Japanese governments increasingly perceive culture as a national resource on an international scale. However, neo-Ottomanism and Cool Japan represents radical challenges to the state-centric projects of modernization because they involve reviving local cultural elements and imply the slackening of the state's incessant pursuit of modernity.

The challenges to state-centric modernity took place in the context of neoliberal globalization, which is the second, and more recent, global transformation that aligned Turkish and Japanese experiences with their imperial pasts. Following the rise of neoliberalism around the world, both countries experienced an economic crisis and a reshaping of the cultural domain. In an environment of corporatization and privatization of the media, globalization of

51 lan Condry and Yuiko Fujita, "Introduction," International Journal of Japanese Sociology 20, no. 1 (2011): 2-3; lan Condry, "Post-3/11 Japan and the Radical Recontextualization of Value: Music, Social Media, and End-around Strategies for Cultural Action," International Journal of Japanese Sociology 20, no. 1 (2011): 4-17. 
communication channels, and the rise of the internet as a new standard medium, popular culture began to slip out of governmental efforts of domestication and control. For example, we need to remember how government officials in Turkey frequently blame soap operas for misrepresenting Ottoman history, which illustrates the conflicting goals of governmental projects and popular cultural products. Neo-Ottomanism and Cool Japan represent endeavors to create a global and exportable brand out of an exoticized and reified national culture and to reclaim the political influence of the former empires in new "soft" formats. However, the end product in popular culture eventually acquires a life of its own and becomes subjected to multiple interpretations, locally and globally. Turkey and Japan have vexed imperial pasts and countries surrounding them harbor unpleasant memories of former imperial rule, which creates serious complications and tensions with the reception of cultural exports. Even when popular culture appears to be embraced in the form of TV series, music, movies, or other cultural products, this does not automatically translate into "soft power." In Turkey, recent developments in the Middle East raised questions about Turkey's ambitious foreign policy goals; in Japan, the post-disaster concerns and demographic challenges with growing creative industries in other parts of Asia cast doubts on the image of the country. The results of this inquiry clearly illustrate how the rise of cultural constructs remains a complex and multifaceted process with many contributing factors to consider.

\section{References}

Abel, Jonathan E. "Can Cool Japan Save Post-Disaster Japan? On the Possibilities and Impossibilities of a Cool Japanology." International Journal of Japanese Sociology 20, no. 1 (2011): 59-72.

Allison, Anne. "The Cool Brand, Affective Activism and Japanese Youth." Theory, Culture \& Society 26, nos. 2-3 (2009): 89-111.

Ang, len. Living Room Wars: Rethinking Media Audiences for a Postmodern World. London and New York: Routledge, 1996.

Azuma, Hiroki, Otaku: Japan's Database Animals. Minneapolis: University of Minnesota Press, 2009.

— - ed. Nihonteki Sōzōryokuno Mirai: Kūru Japanorojīno Kanōsei. Tokyo: NHK Books, 2011.

Benhaïm, Yohanan, and Kerem Öktem. "The Rise and Fall of Turkey's Soft Power Discourse." European Journal of Turkish Studies, no. 21 (2015). https://doi.org/10.4000/ejts.5275.

Bhutto, Fatima. "How Turkish TV Is Taking over the World." The Guardian, September 13, 2019. Retrieved on March 24, 2020 from www.theguardian.com/tv-and-radio/2019/sep/13/turkish-tv-magnificentcentury-dizi-taking-over-world.

Bilefsky, Dan. "Frustrated with West, Turks Revel in Empire Lost." New York Times, December 5, 2009, A9. Bukh, Alexander. "Revisiting Japan's Cultural Diplomacy: A Critique of the Agent-Level Approach to Japan's Soft Power." Asian Perspective, no. 38 (2014): 461-85.

Cabinet Office of Japan. "Kaisaijōkyō," Chitekizaisansenryakukaigi (March 20, 2002 to January 16, 2003). Retrieved on March 19, 2015 from www.kantei.go.jp/jp/singi/titeki/kaisai-dex.html.

Cabinet Office of Japan. "Kūru Japan senryaku.” 2020. Retrieved on February 1, 2020 from www.cao.go.jp/ cool_japan/about/about.html. 
Condry, Ian. "Post-3/11 Japan and the Radical Recontextualization of Value: Music, Social Media, and Endaround Strategies for Cultural Action." International Journal of Japanese Sociology 20, no. 1 (2011): 4-17.

Condry, Ian, and Yuiko Fujita. "Introduction." International Journal of Japanese Sociology 20, no. 1 (2011): $2-3$.

Daliot-Bul, Michal. "Asobi in Action: Contesting the Cultural Meanings and Cultural Boundaries of Play in Tokyo from the 1970s to the Present." Cultural Studies 23, no. 3 (2009): 355-80.

_. "Japan Brand Strategy: The Taming of 'Cool Japan' and the Challenges of Cultural Planning in a Postmodern Age." Social Science Japan Journal 12, no. 2 (2009): 247-66.

Ergin, Murat. "On Humans, Fish, and Mermaids: The Republican Taxonomy of Tastes and Arabesk." New Perspectives on Turkey, no. 33 (2005): 63-92.

Ergin, Murat, and Yağmur Karakaya. "Between Neo-Ottomanism and Ottomania: Navigating State-Led and Popular Cultural Representations of the Past." New Perspectives on Turkey 56 (2017): 33-59.

Fisher Onar, Nora. "Constructing Turkey Inc.: The Discursive Anatomy of a Domestic and Foreign Policy Agenda." Journal of Contemporary European Studies 19, no. 4 (2011): 463-73.

Frith, Simon. "The Good, the Bad, and the Indifferent: Defending Popular Culture from the Populists." Diacritics 21, no. 4 (1991): 102-15.

Gordon, Andrew D. "Consumption, Consumerism, and Japanese Modernity." In The Oxford Handbook of the History of Consumption, edited by Frank Trentmann, 485-504. Oxford: Oxford University Press, 2012.

Haberman, Clyde. “In Japan, 'Oshin' Means It's Time for a Good Cry.” New York Times, March 11, 1984. Retrieved on March 8, 2016 from www.nytimes.com/1984/03/11/arts/in-japan-oshin-means-it-stime-for-a-good-cry.html.

Heng, Yee-Kuang. "Beyond 'Kawaii' Pop Culture: Japan's Normative Soft Power as Global TroubleShooter." The Pacific Review 27, no. 2 (2014): 169-92.

Huang, Shuling. "Nation-Branding and Transnational Consumption: Japan-Mania and the Korean Wave in Taiwan." Media, Culture \& Society 33, no. 1 (2011): 3-18.

Hurriyet Daily News, "Turkey Ranks Second in TV Series Exports: Minister." November 17, 2017. Retrieved on July 25, 2018 from www.hurriyetdailynews.com/turkey-ranks-second-in-tv-series-exportsminister-122562.

Iwabuchi, Koichi, ed. Feeling Asian Modernities: Transnational Consumption of Japanese TV Dramas. Hong Kong: Hong Kong University Press, 2004.

- Recentring Globalization: Popular Culture and Japanese Transnationalism. Durham, NC and London: Duke University Press, 2002.

—. "Pop-Culture Diplomacy in Japan: Soft Power, Nation Branding and the Question of 'International Cultural Exchange'." International Journal of Cultural Policy 21, no. 4 (2015): 419-32.

Iwabuchi, Koichi, Eva Tsai, and Chris Berry. Routledge Handbook of East Asian Popular Culture. London and New York: Routledge, 2017.

Japan Foundation. “Terebibangumino Kaigaitenkai." 2018. Retrieved on July 25, 2018 from www.jpf.go.jp/ j/project/culture/media/tv/index.html.

Kadıoğlu, Ayşe. "The Paradox of Turkish Nationalism and the Construction of Official Identity." In Turkey: Identity, Democracy, Politics, edited by Sylvia Kedourie, 177-93. London and Portland, OR: Frank Cass, 1996.

Karakaya, Yağmur. "The Conquest of Hearts: The Central Role of Ottoman Nostalgia within Contemporary Turkish Populism." American Journal of Cultural Sociology 8, no. 2 (2020): 125-57.

Karaman, Ozan. "Urban Neoliberalism with Islamic Characteristics." Urban Studies 50, no. 16 (2013): 3412-27. Kraidy, Marwan M., and Omar Al-Ghazzi. "Neo-Ottoman Cool: Turkish Popular Culture in the Arab Public Sphere." Popular Communication 11, no. 1 (2013): 17-29.

Lam, Peng Er. “Japan's Quest for 'Soft Power': Attraction and Limitation.” East Asia 24, no. 4 (2007): 349-63. Matsui, Takeshi. "Nation Branding through Stigmatized Popular Culture: The 'Cool Japan' Craze among Central Ministries in Japan." Hitotsubashi Journal of Commerce and Management 48, no. 1 (2014): 81-97.

McGray, Douglas. “Japan's Gross National Cool." Foreign Policy, no. 130 (2002): 44-54. 
McVeigh, Brian J. Nationalisms of Japan: Managing and Mystifying Identity. Asia/Pacific/Perspectives. Lanham, MD: Rowman \& Littlefield, 2004.

Miller, Laura. "Cute Masquerade and the Pimping of Japan." International Journal of Japanese Sociology 20, no. 1 (2011): 18-29.

Miyadai, Shinji. "Kawaii No Honshitsu." In Nihonteki Sōzōryokuno Mirai: Kūru Japanorojīno Kanōsei, edited by Hiroki Azuma, 73-91. Tokyo: NHK Books, 2011.

Mori, Yoshitaka. "The Pitfall Facing the Cool Japan Project: The Transnational Development of the Anime Industry under the Condition of Post-Fordism." International Journal of Japanese Sociology 20, no. 1 (2011): 30-42.

Moudouros, Nikos. "The 'Harmonization' of Islam with the Neoliberal Transformation: The Case of Turkey." Globalizations 11, no. 6 (2014): 843-57.

Netflix. 2018. Magnificent Century. Retrieved on July 25, 2018 from www.netflix.com/title/80089559.

NHK. 2008. "Archives Blog: Renzoku Terebishōsetsu Oshin Hankyōhen (2)." NHK (Nippon Hoso Kyokai or Japan Broadcasting Corporation). Retrieved on March 6, 2018 from www.nhk.or.jp/archives-blog/ genre/drama/9785.html.

Nye, Joseph S. "Soft Power." Foreign Policy, no. 80 (1990): 153-71.

Otmazgin, Nissim Kadosh. "Contesting Soft Power: Japanese Popular Culture in East and Southeast Asia." International Relations of the Asia-Pacific 8, no. 1 (2008): 73-101.

Roberts, Glenda S. "An Immigration Policy by Any Other Name: Semantics of Immigration to Japan." Social Science Japan Journal 21, no. 1 (2018): 89-102.

Sakai, Naoki. "The West: A Dialogic Prescription or Proscription?" Social Identities 11, no. 3 (2005): 177-95. Seaton, Phillip, and Takayoshi Yamamura. "Japanese Popular Culture and Contents Tourism." Japan Forum 27, no. 1 (2015): 1-11.

Shinohara, Chika. "Health-Care Work in Globalization: News Reports on Care Worker Migration to Japan." International Journal of Japanese Sociology 25, no. 1 (2016): 7-26.

Tanaka, Stefan. Japan's Orient: Rendering Pasts into History. Berkeley: University of California Press, 1993. Valaskivi, Katja. "A Brand New Future? Cool Japan and the Social Imaginary of the Branded Nation." Japan Forum 25, no. 4 (2013): 485-504.

Yang Erdem, Chien. "Ottomentality: Neoliberal Governance of Culture and Neo-Ottoman Management of Diversity." Turkish Studies 18, no. 4 (2017): 710-28. 